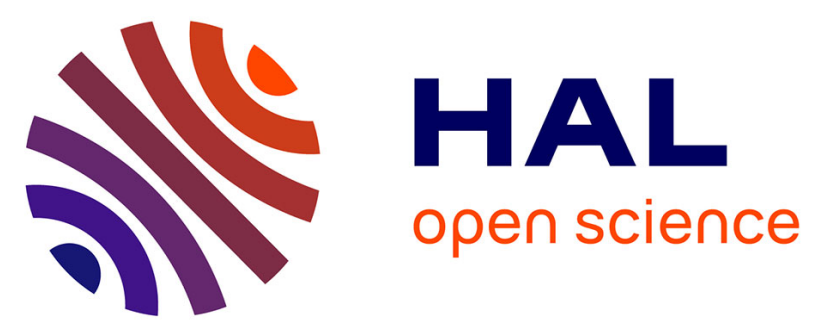

\title{
Climatology in Mauritius 1983-2005: potential solar radiation modulation by Quasi-Biennial oscillation and El Niño-Southern oscillation
}

Miloud Bessafi, M.R. Lollchund, Jean-Pierre Chabriat, Jean-Daniel Lan Sun Luk, Patrick Jeanty

\section{To cite this version:}

Miloud Bessafi, M.R. Lollchund, Jean-Pierre Chabriat, Jean-Daniel Lan Sun Luk, Patrick Jeanty. Climatology in Mauritius 1983-2005: potential solar radiation modulation by Quasi-Biennial oscillation and El Niño-Southern oscillation. Progress in Industrial Ecology, An International Journal, 2017, 11 (1), pp.97-103. 10.1504/PIE.2017.086160 . hal-01626579

\section{HAL Id: hal-01626579 \\ https://hal.univ-reunion.fr/hal-01626579}

Submitted on 6 Nov 2017

HAL is a multi-disciplinary open access archive for the deposit and dissemination of scientific research documents, whether they are published or not. The documents may come from teaching and research institutions in France or abroad, or from public or private research centers.
L'archive ouverte pluridisciplinaire HAL, est destinée au dépôt et à la diffusion de documents scientifiques de niveau recherche, publiés ou non, émanant des établissements d'enseignement et de recherche français ou étrangers, des laboratoires publics ou privés. 


\title{
Climatology in Mauritius 1983-2005 : potential solar radiation modulation by Quasi-Biennial oscillation and EI Niño-Southern oscillation
}

\author{
M. Bessafi \\ Laboratoire d'Energétique, d'Electronique et Procédés, \\ University of La Réunion, Cedex 9, France \\ Email: miloud.bessafi@univ-reunion.fr \\ M.R. Lollchund* \\ Department of Physics, Faculty of Science, \\ University of Mauritius, Réduit 80837, Republic of Mauritius \\ Email: r.lollchund@uom.ac.mu \\ ${ }^{*}$ Corresponding author \\ J.P. Chabriat, J.D. LanSunLuk
and P. Jeanty \\ Laboratoire d'Energétique, d'Electronique et Procédés, \\ University of La Réunion, Cedex 9, France \\ Email: jean-pierre.chabriat@univ-reunion.fr \\ Email: jean-daniel.lan-sun-luk@univ-reunion.fr \\ Email: Patrick.jeanty@univ-reunion.fr
}

\begin{abstract}
The monthly variability of solar radiation over Mauritius is examined using monthly data from CMSAF (Satellite Application Facility on Climate Monitoring) satellite during the period January 1983December 2005. It is found that the series analysed have periodicities which can be related to two well-known oscillations (Quasi-Biennal Oscillation - QBO and El Niño Southern Oscillation - ENSO). The results highlight a significant modulation of solar radiation by QBO that indicate the possible modulation of convective activity and cloud cover by this oscillation. A temporal conjunction between El-Nino events and high solar radiation disturbances is shown. Nevertheless, it was difficult to assess a simple correlation between ENSO and solar radiation variability over the studied period. This paper focuses on interannual oscillation and omits the intra-seasonal tropical perturbations (Madden Julian Oscillation, Indian Ocean Dipole, Southern Antarctic Mode). This demonstrates a first approach on the interannual solar radiation variability over Mauritius.
\end{abstract}


Keywords: solar radiation; QBO; Quasi-Biennal oscillation; ENSO; El Niño-Southern oscillation; interannual; climate change.

Reference to this paper should be made as follows: Bessafi, M., Lollchund, M.R., Chabriat, J.P., LanSunLuk, J.D. and Jeanty, P. (2017) 'Climatology in Mauritius 1983-2005: potential solar radiation modulation by Quasi-Biennial oscillation and El Niño-Southern oscillation', Progress in Industrial Ecology - An International Journal, Vol. 11, No. 1, pp.97-103.

Biographical notes: M. Bessafi is Full First Class Professor of Meteorology and Physics of Environment at the University of La Réunion. Since 2004, he is a member of LE2P (Energy, Electronics and Process) Lab at University of La Réunion working on solar energy, mapping of solar irradiation, solar variability in southwest Indian Ocean and climate change. He has published numerous papers in topics related to atmospheric physics, aerosols, tropical meteorology, and renewable energy.

M.R. Lollchund is currently a Senior Lecturer and Head of the Physics Department at the University of Mauritius. His research interests include climate modelling, renewable energy, computational fluid dynamics and computational electromagnetics. He has published several papers in refereed journals and conference proceedings.

J.P. Chabriat is Full First Class Professor of Mechanical Engineering, Control Systems Engineering and head of LE2P (Energy, Electronics and Process) Lab since 2006. He is also Dean of the Faculty of Science \& Technology at University of La Réunion. He has published several papers in topics related to control systems engineering, fuel cell, electronics and renewable energy.

J.D. LanSunLuk is Full First Class Professor of Electrical, Electronics, Photonics and Systems engineering. Since 1990, he is member of the LE2P (Energy, Electronics and Process Lab) Lab at the University of La Réunion. $\mathrm{He}$ has published numerous papers in topics related to rectenna, wireless energy, applied solar energy and electronics and renewable energy.

P. Jeanty is Research Engineer in the LE2P (Energy, Electronics and Process) $\mathrm{Lab}$ at the University of La Réunion. He is in charge of solar energy sensors network and fuel cell systems in the lab. He has published papers in topics related to applied solar energy and electronics and renewable energy.

This paper is a revised and expanded version of a paper entitled 'Climatology in Mauritius 1983-2005: potential solar radiation modulation by QBO and ENSO' presented at the 4th International Conference on Renewable Energy: Generation and Applications (ICREGA 2016), Belfort, France, 8-10 February, 2016.

\section{Introduction}

Mauritius is a small-island developing state (SIDS) located in the Southwest Indian Ocean (between $19^{\circ} 50^{\prime} \mathrm{S}$ and $20^{\circ} 32^{\prime} \mathrm{S}$ latitudes and $57^{\circ} 18^{\prime} \mathrm{E}$ and $57^{\circ} 46^{\prime} \mathrm{E}$ longitudes: $890 \mathrm{~km}$ off the east coast of Madagascar). The island covers a surface of roughly 
$1875 \mathrm{~km}^{2}$ and eroded topography with hills, plateau, river valley and plains (Nigel and Rughooputh, 2009). The highest altitude of the island is $828 \mathrm{~m}$ at Piton de la Petite Rivière Noire. Typically, weather prevailing over Mauritius is a tropical maritime climate with two distinct seasons. During austral winter from May to November, the Hadley-Walker cell circulation strengthens and produces steady low-level easterly tradewinds and upper-level westerly winds. This is the dry and windy season. In austral summer, the trade-winds weaken and wet conditions are dominant, especially from January to April with strong convective activity and cloudy sky in relation with Inter Tropical Convergence Zone (ITCZ). Additionally to this, the weather is often driven by tropical perturbations (Monsoon, Madden Julian Oscillation, Tropical cyclones) throughout the year and by the El Niño-Southern Oscillation (ENSO) over the interannual time scale (Senapathi et al., 2010).

The use of renewable energy resource remains a challenge for the island due to its vulnerability to climate-change impacts. As pointed out by Jeetah et al. (2013), Mauritius has a significant potential of solar energy resource and the expertise to use this renewable energy through the photovoltaic technology. More recently, Ramgolam and Soyjaudah (2015) have used four sets of solar radiation parameters (Sunshine hour, Global Horizontal Irradiance, monthly average insolation, sky clearness index, climatological yearly solar radiation) and revealed relevant information on the variability of solar radiation under the daily, monthly and yearly scale over Mauritius. As mentioned previously, the weather prevailing over the island is highly variable through different time scale. Moreover, solar radiation being an intermittent energy resource due to cloud cover adds up to such variability in the weather. In his study, Lean (2014) highlighted a correlation between interannual oscillation (ENSO) and total cloud cover for the six $30^{\circ}$ - latitude bands over the globe. He pointed out a decrease of total cloud cover from 1984 to 1997. Moreover, low-level (resp., middle and upper) cloud cover decreased (resp., increased) during 1984-2009 period. This paper focuses on the observed solar radiation variability over Mauritius under interannual time scale.

\section{Data and analysis}

The data used for this study is surface global solar radiation derived from satellite observations. They are obtained from the EUMETSAT's Satellite Application Facility on Climate Monitoring (CM SAF). This is a gridded product on high-resolution $\left(15 \times 15 \mathrm{~km}^{2}\right)$ which is public and free-of-charge via CM SAF webpage (http://www.cmsaf.eu). For more details, see the paper of Schulz et al. (2009). Climate indices used in this paper are monthly time series from NOAA's website (http://www.esrl.noaa.gov/psd/data/climateindices/list/). OLR is used as a proxy for convective activity (http://www.esrl.noaa.gov/psd/data/gridded/data.interp_OLR.html). As shown in Figure 1(a), solar radiation over Mauritius exhibits seasonal cycle through the 1983-2005 period record. In addition, there is no significant observed trend. Moreover, we can notice interannual component in the spectrum of solar radiation as well (Figure 1(b)). 
Figure 1 (a) Monthly global solar radiation observed during 1983-2005 period and (b) power spectrum of monthly solar radiation

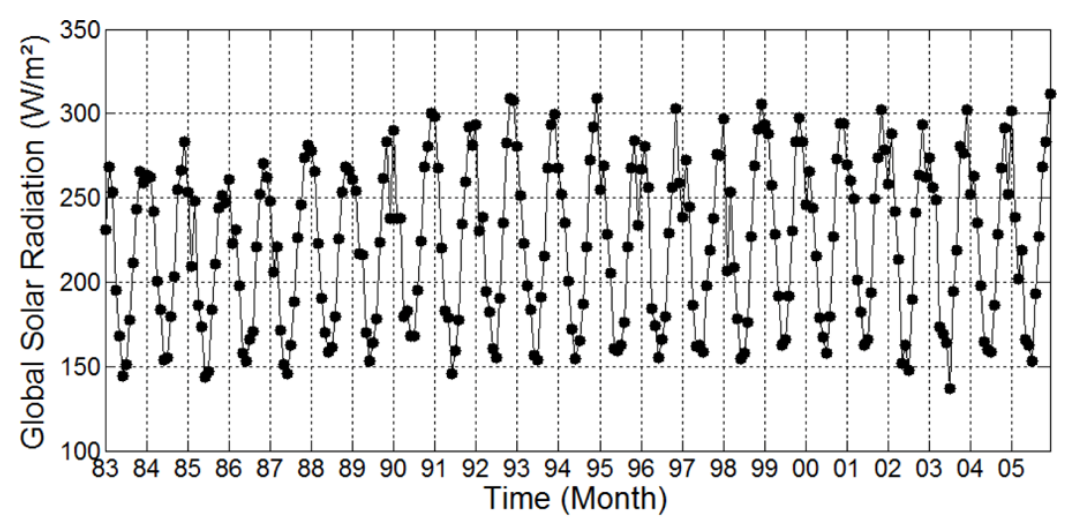

(a)

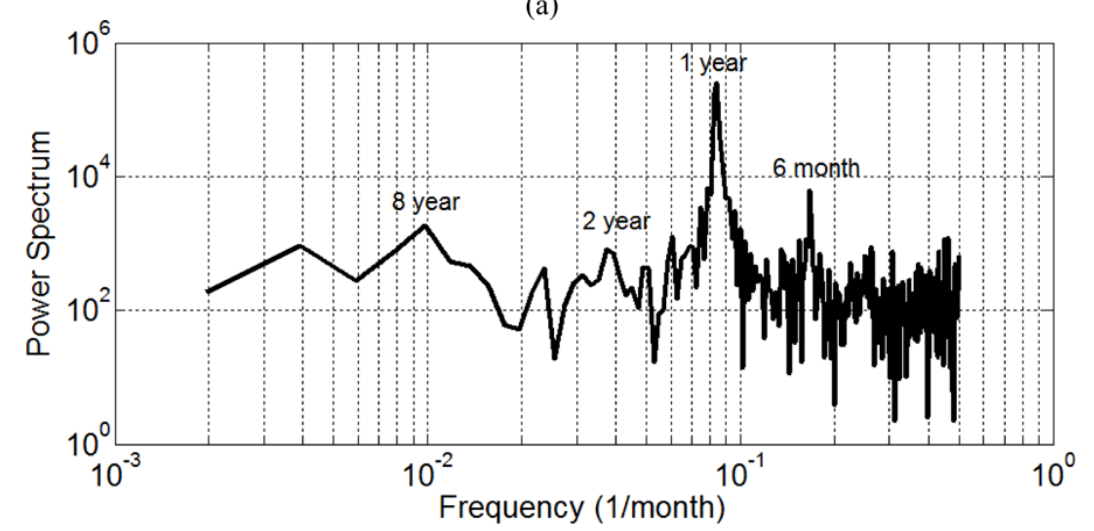

(b)

The El Niño-Southern Oscillation (ENSO) and the Quasi-Biennal Oscillation (QBO) are the most dominant interannual mode in the troposphere and the stratosphere, respectively. The former is associated with a coupled ocean-atmosphere interaction and covers large quasi-periodic time scale (3-7 years timescale) and has a planetary teleconnection (Diaz et al., 2001). The QBO is a zonal stratospheric wind oscillation and have shorter period of alternation within 24-30 month range (Baldwin et al., 2001). Some authors have pointed non-linear interaction between these two oscillations and trigger the precipitation and cloud cover (Lau and Sheu, 1988; Claud and Terray, 2007).

Figure 2(a) depicts the yearly anomalies of minimum (resp., maximum) solar radiation observed over Mauritius during the period January 1983-December 2005 and the departure from the normal condition in terms of standard deviation. Only years which exceed two or three standard deviations are labelled. Figure 2(b) highlights the state of ENSO and QBO state of the atmosphere throughout the period. Eleven years within 1983-2005 reveal an abnormal solar radiation level over Mauritius and could be affected by ENSO and QBO separately or combined (coupled). Lower maximum and minimum solar radiation was observed during El Niño's 1983, which was one of the strongest El Niño events of the twentieth century. Other El Niño's year (Moderate and Strong) was retrieved. During 1997, the QBO was in its eastward phase and the solar radiation exhibits a lower maximum and higher minimum. 
Figure 2 (a) Yearly solar radiation standardised anomalies over Mauritius during 1950-2013 period and (b) Monthly SOI and QBO indices for the same period

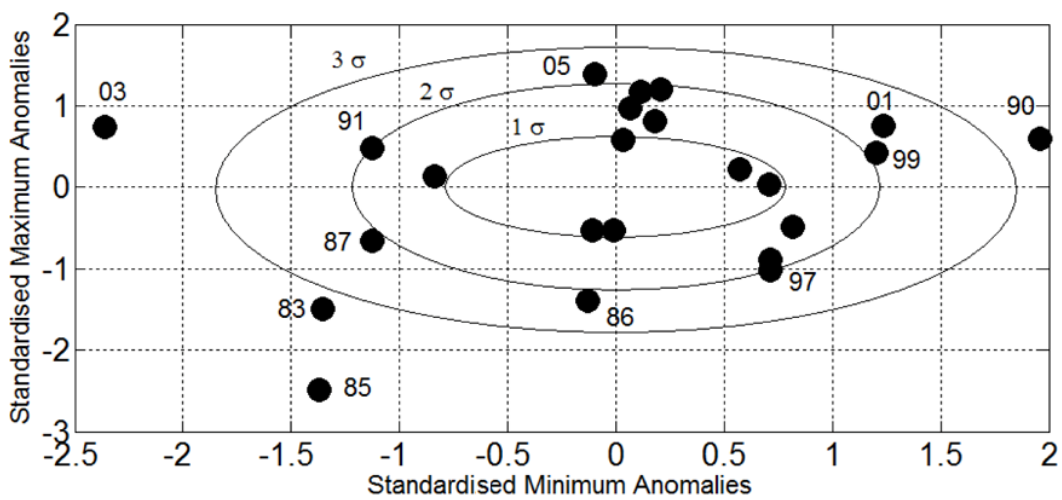

(a)

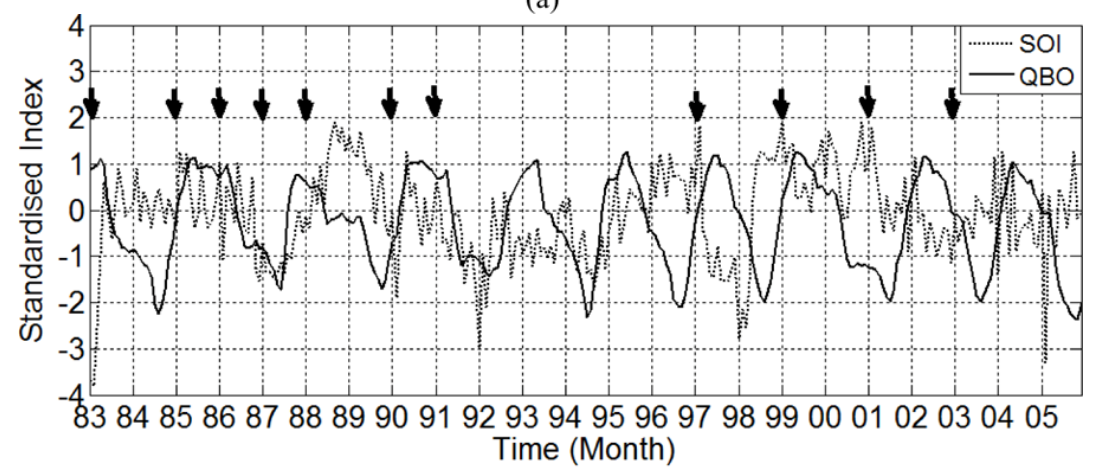

(b)

Arrows represent the year in which solar radiation anomalies exceed at least twice standard deviation.

\section{Correlation analysis}

In order to assess the relationship between solar radiation variability and interannual oscillations, their correlation coefficient is computed. The correlation coefficient $r$ between two sets of sampling data $x_{i}$ and $y_{i}(i=1, \ldots, n)$ is obtained using the formula

$$
r=\left[\sum_{i=1}^{n}\left(x_{i}-\bar{x}\right)\left(y_{i}-\bar{y}\right)\right]\left[\sum_{i=1}^{n}\left(x_{i}-\bar{x}\right)^{2} \sum_{i=1}^{n}\left(y_{i}-\bar{y}\right)^{2}\right]^{-1 / 2},
$$

where $\bar{x}$ and $\bar{y}$ are the mean values of $x$ and $y$, respectively. The values of $r$ are within $[-1,1]$. If $|r|<0.3$, then the correlation of the two samples is considered to be low (or no correlation). If $0.3 \leq|r|<0.7$, then the samples correlate moderately with each other. For $|r| \geq 0.7$, the two datasets are said to highly correlate with each other (Aron et al., 2011).

Figure 3(a) displays positive correlation between yearly solar radiation range (maximum minus minimum) and yearly QBO range. This result reveals that QBO could have an impact on the solar radiation variability over Mauritius. Conversely, there is no 
significant correlation between solar radiation and SOI. It means that the impact of ENSO events on the solar radiation is more complex. Nevertheless, the link with convective activity (cloud cover) and solar radiation is clear as shown in Figure 3(b).

Figure 3 (a) Yearly solar radiation range vs. yearly QBO index observed over Mauritius during 1983-2005 period and (b) yearly deseasonalised solar radiation range vs. OLR range observed for the same period

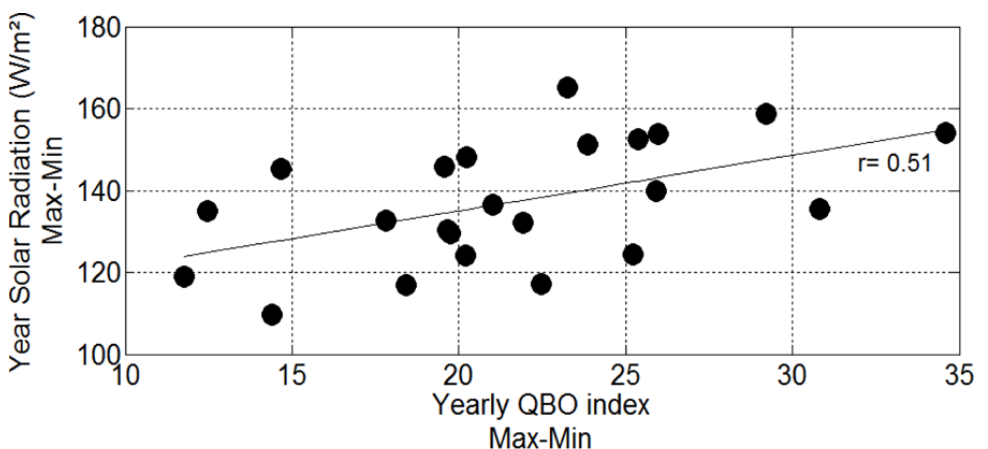

(a)

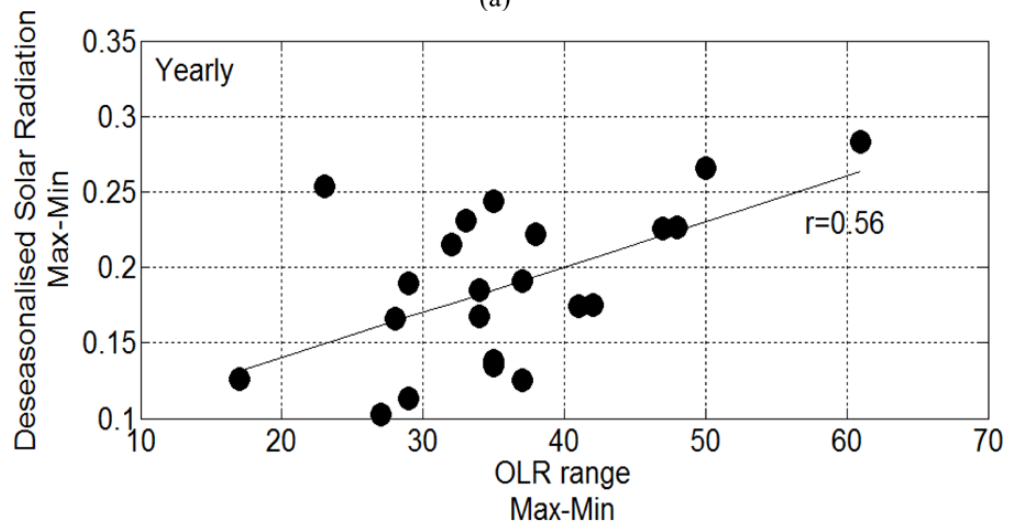

(b)

\section{Conclusion}

This study shows that solar radiation range has a seasonal as well as an interannual variability. During the period January 1983-December 2005, moderate and strong El Niño events have been identified to trigger solar radiation disturbances to highest levels. Nevertheless, the correlation remains difficult to assess. Conversely, QBO seems to significantly modulate the yearly seasonal cycle solar radiation over Mauritius. OLR analysis confirms the modulation of convective activity and cloud cover over interannual timescale. Quasi-periodicity and possible interactions with intra-seasonal atmospheric perturbations (Madden Julian Oscillation, Indian Ocean Dipole and Southern Antarctic Mode) lead to intermittent solar radiation basically. Mixing modes through several decades yield to non-linear and multivariate analysis which could be further studied. 


\section{References}

Aron, A., Coups, E.J. and Aron, E.N. (2011) Statistics for the Behavioral and Social Sciences: A Brief Course, 5th ed., Pearson, Upper Saddle River, NJ.

Baldwin, M.P., Gray, L.J., Dunkerton, T.J., Hamilton, K., Haynes, P.H., Randel, W.J., Holton, J.R., Alexander, M.J., Hirota, I., Horinouchi, T., Jones, D.B.A., Kinnersley, J.S., Marquardt, C., Sato, K. and Takahashi, M. (2001) 'The Quasi-Biennal oscillation', Reviews of Geophysics, Vol. 39, No. 2, pp.179-229.

Claud, C. and Terray, O. (2007) 'Revisiting the possible links between the Quasi-Biennial oscillation and the Indian summer monsoon using NCEP R-2 and CMAP fields', Journal of Climate, Vol. 20, pp.773-787.

Diaz, H.F., Hoerling, M.P. and Eischeid, J.K. (2001) 'ENSO variability, teleconnections and climate change', International Journal of Climatology, Vol. 21, pp.1845-1862.

Jeetah, P., Surroop, D., Mohee, R., Filho, W.L., Schulte, V. and Gottwald, J. (2013) 'Feasibility of using solar energy as a source of renewable energy in Mauritius under collaboration of DIREKT', in Leal Filho, W., Mannke, F., Mohee, R., Schulte, V., Surroop, D. (Eds.): ClimateSmart Technologies. Climate Change Management, Springer, Berlin, Heidelberg.

Lau, K.M. and Sheu, P.J. (1988) 'Annual cycle, Quasi-Biennal oscillation, and southern oscillation in global precipitation', Journal of Geophysical Research, Atmospheres, Vol. 93, No. D9, pp.10975-10988.

Lean, J. (2014) 'Late twentieth-century warming and variations in cloud cover', Atmospheric and Climate Sciences, Vol. 4, pp.727-742.

Nigel, R. and Rughooputh, S. (2009) 'Mapping of monthly soil erosion risk of mainland Mauritius and its aggregation with delineated basins', Geomorphology, Vol. 114, pp.101-114.

Ramgolam, Y.K. and Soyjaudah, K.M.S. (2015) 'Unveiling the solar resource potential for photovoltaic applications in Mauritius', Renewable Energy, Vol. 77, pp.94-100.

Schulz, J., Albert, P., Behr, H.D., Caprion, D., Deneke, H., Dewitte, S., Durr, B., Fuchs, P., Gratzki, A., Hechler, P., Hollmann, R., Johnston, S., Karlsson, K.G., Manninen, T., Muller, R., Reuter, M., Riihela, A., Roebeling, R., Selbach, N., Tetzlaff, A., Thomas, W., Werscheck, M., Wolters, E. and Zelenka, A. (2009) 'Operational climate monitoring from space: the EUMETSAT satellite application facility on climate monitoring (CM-SAF)', Atmospheric Chemistry and Physics, Vol. 9, pp.1687-1709.

Senapathi, D., Underwood, F.M., Black, E., Nicoll, M.A.C. and Norrisa, K. (2010) 'Evidence for long-term regional changes in precipitation on the East Coast Mountains in Mauritius', International Journal of Climatology, Vol. 30, pp.1164-1177. 